\title{
COPING STYLES OF STRESS AND THE LEVEL OF SOCIAL COMPETENCE OF THE STAFF MEMBERS INVOLVED IN THE HANDLING OF PASSENGERS ON LOT POLISH AIRLINES' FLIGHTS
}

\author{
Jan F. TERELAK ${ }^{1}$, Katarzyna MAKUCH ${ }^{2}$ \\ ${ }^{1}$ Military Institute of Aviation Medicine, Department of Aviation Psychology, Warsaw, Poland \\ ${ }^{2}$ Cardinal Stefan Wyszynski University, Institute of Psychology, Warsaw, Poland
}

Source of support: Own sources

Author's address: Jan F. Terelak, Military Institute of Aviation Medicine, Department of Aviation Psychology, Krasińskiego 54/56 Street, 01-755 Warszawa, Poland, e-mail: jterelak@wiml.waw.pl

Introduction: Both in the literature of the subject and in everyday life there is an interest in the relation between social competences and the ability to cope with the demands of life, especially with stressful situations. The aim of the study was to determine the relationship between coping styles of stress in the perspective of N.S.Endler and J.D.A. Parker with social competences according to the concept of A. Matczak.

Methods: To evaluate social competences defined as acquired skills of coping with social contacts, Anna Matczak's Questionnaire of Social Competences was used to diagnose the effectiveness of functioning in specific situations requiring social interaction. Coping styles of stress were studied using Coping Inventory for Stressful Situations of N.A. Endler and J.D.A. Parker, designed to evaluate coping styles of stress in the sense of R. Lazarus' interactive stress model.

Results: The statistically significant differences in the scope of individual social competences were obtained among people who prefer different coping styles of stress. It was found, among other things, that people with a style focused on emotions are characterized by lower effectiveness of social competences, manifested mainly in interpersonal relations requiring assertive behaviour, and that people who prefer the avoiding style of coping with stress are more susceptible to searching for social contacts.

Discussion: Although the direction of the observed relationships is in line with the theoretical assumptions and results at the level of subject literature, the lack of relation between the task style of coping with stress and assertiveness, as a feature included in social competences requires further reflection. The authors point out that the possible reason

Tables: 4 - References: 25 - Full-text PDF: http://www.pjambp.com • Copyright (C) 2016 Polish Aviation Medicine Society, ul. Krasińskiego 54/56, 01-755 Warsaw, license WIML • Indexation: Index Copernicus, Polish Ministry of Science and Higher Education 
may have been the specificity of the studied group, in which various social interactions are constantly present on the professional level, which may have an influence on the underestimated self-assessment of own social competences.

Conclusions: The study results indicate significant differences within the scope of the individual social competences in people with various coping styles of stress.

Keywords: coping styles of stress, social competences, assertiveness

\section{INTRODUCTION}

The aim of this study is to assess the relationship between coping styles of stress and social competences, as well as the differences in the studied variables between the examined groups.

\section{Styles of coping with stress}

The concept of coping styles of stress refers to the transactional concept of stress by R. Lazarus and S. Folkman [11], whose main thesis is that stress is a result of cognitive processes, that is, the way one perceives and understands one's relationship with the environment, and that stimulated emotions can in turn influence cognitive processes. This theory draws attention to the interaction between man and his environment. This relationship has the status of a "transaction" because both parties to the relationship have an influence on each other. Situations influence the man and the man, through their actions, can changetheenvironment. Moreover, the person and his surroundings are a whole as a new quality. It is impossible to understand a person without knowing the environment in which he or she functions. In some situations, a person may assess their situation as excessively burdensome or exceeding their resources and capabilities of dealing. The authors assumed that in stressful situations cognitive factors are superior to emotional ones. Cognitive evaluation is primary and its course determines the emotions that are secondary to it. Emotions coexist with cognitive evaluation and are dynamic. Emotional process, comes together with the initial assessment process into the stress transaction. In the revised concept of dealing with the stress of R. Lazarus [10] and S. Folkman [6] we meet two aspects of emotions occurring in the stress transaction. Emotions are recognised as a result of cognitive evaluation or as an indicator of the effects of coping, which in the process of revaluation may positively or negatively affect coping stress. The secondary evaluation process starts when, following the initial assessment, the relationship is considered stressful due to remedial action. The processes of primary and secondary evaluation take place at the same time and are related to each other, at the same time being the basis for decisions on the choice of strategies for coping with stress, which over time transform into remedial styles, defined as specific instructions determining the differences between people in coping with life stress [22].

In literature there is a significant discrepancy in the accepted theoretical bases, different definition and operationalisation of the concept of coping stress [10], as well as the variety of methods of remedial behaviour testing [8]. These difficulties can be avoided by diversifying concepts: style, strategy and the process of coping with stress. In this paper, the process is understood as a sequence of strategies changing over time, related to the changes in the situation and psychophysical state of an individual. It is the whole activity undertaken in a given stress situation. Strategy is defined as a specific activity, cognitive and behavioural efforts that an individual makes in a specific stress situation. The coping styles of stress is usually defined as a permanent, personality-dependent disposition of an individual to a specific way of dealing with stressful situations. The concept of coping with stress underlines the role of subjective factors $[7,25]$.

So far, in the research on coping styles of stress, there are two main proposals for their classification: the first, inspired by the classical psychoanalysis described by S. M. Miller [16] as an activity connected on one hand with the search for information about stress in direct confrontation with it, and on the other hand - avoiding confrontation with stress by displacing, denying unpleasant experiences, etc. and the second typology based on N.S. Endler and J.D.A. Parker [5], who based on the Lazarus and Folkman [11] concepts proposed a taxonomy of coping styles of stress, dividing them into: focused on task, emotions and avoidance, and the latter on looking for social contacts and engaging in replacement activities. 


\section{Social competences}

Social competences in the literature of the subject are described by means of different terminology, e.g. social intelligence, competences, interpersonal skills, emotional intelligence, etc. An so, for example, A. Matczak [13] draws attention to the differences between social competences and social intelligence. Social competences are a determinant of the effectiveness of functioning in real life situations, especially social ones, and social intelligence, according to E. L. Thorndike [23], can be defined as the ability to understand other people and to act wisely in dealing with them.

There are several ways of defining social competences, some of which focus on their communication aspect $[3,9,19,24]$ i.e. effective communication of interaction partners. Others in turn focus on the effectiveness of human behaviours [1]. Competences may be expressed in terms of general capacity or ability, in which case we should speak of one general social competence. Such an approach is connected with the assumption of the non-specific nature of man's abilities and interpersonal skills, which are equally manifested in qualitatively diverse interactions [18]. This is a peculiar reference to the construction of the " $g$ " factor in the theory of intelligence, however, the difference is that competence manifests itself in social contact situations, not in problems requiring broadly understood intellectual involvement [2].

Competence is also sometimes defined as adaptive ability or skill, and its indicator is e.g. the relevance of the statement to an objective social situation, as well as a subjective picture of the situation, created by the partner. The criterion of social competence in this sense may be the sociometric position of an individual in a group or the number of friends [9]. A different view of social competences focuses on the ability to build emotional bonds with people. Competence, referred to as relational, concerns skillfully building, developing and maintaining relationships with other people, which positively correlates with self-esteem and negatively with shame and fear of society.

A clear summary of the previous theories, which are the source of the concept of social competences, is the concept of A. Matczak [15], according to which social competences are understood as the skills of coping in social situations, developed in the course of training which takes place in reallife situations. Competences, however, are based on intelligence and personality, as they determine the intensity and effectiveness of social training. The ability of intelligence, especially social intelligence (ability to process behavioural information) and emotional intelligence (capacity to process emotional information) of the individual depends on the effectiveness of training, but the intensity and type of training depend, to a large extent, on the personality and temperament of the individual $[3,14]$. This concept allows to search for and explain the relationship between the styles of coping with stress and the level of social competences, which is also indicated by some literature data.

\section{Relationships between coping styles of stress and social competences}

Looking for dependencies between coping styles of stress and social competences, at the level of subject literature, it is worth noting a number of individual determinants of coping stress, including, for example, the general level of intelligence, understood as the global ability to act purposefully, to think rationally and to deal effectively with the environment, but also a number of others, such as e.g. personality considerations. And so, for example, the relationships of several personality traits with styles of handling stress were indicated in own studies [21]. Among other things, it was found that a lower level of neuroticism is associated both with the preference for an avoidable coping styles of stress based on social contacts and with the preference for a task-oriented style. The study by A. Matczak [14] confirmed the existence of social competence relationships with some characteristics of temperament, such as e.g. reactivity and mobility of nervous processes in J. Strelau's perspective. The obtained data suggests that high reactivity and low mobility of nervous processes make it difficult to acquire social skills. At the same time, a high level of social competences is not associated with particularly low reactivity or high mobility. Other characteristics of temperament, such as e.g. activity and agility correlate positively with social competences in the area of interpersonal skills, while emotional reactivity shows a negative relationship.

The studies, which directly relate to the undertaken study problem, were conducted by A. Matczak [12] - the author of the Social Competence Questionnaire, whose aim was to establish links between the results of this questionnaire and the coping styles of stress, the studied CISS by N.S. Endler and J.D.A. The author found a statistically significant positive correlation between the task coping styles of stress and high social competences, and a negative one with the style of coping with emotional stress. Taking into account the correlation nature of own research and referring to previously presented theories on both variables, i.e. 
coping styles of stress and social competences, the following research questions were asked:

1. Is there a correlation between coping styles of stress and the level of social competences, understood as complex skills that determine effective functioning in specific social situations?

2. Does the task oriented approach to dealing with stress, which is related to problem orientation, intentional action regardless of emerging emotions, relate to social competences?

3. Does the emotional style, which manifests itself mainly in the protection of the self against unpleasant emotional tension, have a negative impact on the acquisition of social competences, as it hinders efficient and free interpersonal functioning?

4. Does a contact-seeking approach favour the training of social competences?

\section{METHODS}

\section{Research subjects}

The survey involved 61 employees of the LOT Airline Ground Passenger Services Department, including 35 women (59\% of respondents) and 26 men ( $41 \%$ of respondents). The age of the subjects ranged from 23 to 57, with an average of $M=37.8$ and standard deviation $s=9.55$. Most of the respondents have higher education (44\%), while $28 \%$ have secondary education, similarly - post-secondary education - $28 \%$. The mean length of tenure for the subjects was 7.6 with standard deviation $\mathrm{s}=0.29$.

\section{Questionnaire "Coping Inventory for Stressful Situations (CISS)" by N.A. Endler and J.D.A. Parker}

The CISS Questionnaire of Endler and Parker[4] is used to study coping styles of stress and is based on an interactive theoretical model of stress by R. Lazarus [10]. The questionnaire consists of 48 items, which are listed in 5 scales: Style focused on the task, style focused on emotions, style focused on avoiding with 2 subscales: Engaging in replacement activities and looking for social contacts.

Coping Inventory for Stressful Situations (CISS) by N. Endler and J. Parker in the Polish version by Strelau, Jaworowska, Wrzesniewski and Szczepaniak [20]. CISS measures the three styles of coping with stress: Task-Oriented Coping (TOC), Emotion-Oriented Coping (EOC), and AvoidanceOriented Coping (AOC) including Distraction (DIS) and Social Diversion (DIV). Cronbach's alpha for the main scales of the Polish version of CISS is 0.74 to 0.88 , which indicates a satisfactory reliability.

\section{Questionnaire of Social Competences (KKS) by Anna Matczak}

KKS is used to diagnose the effectiveness of functioning in certain situations requiring social interaction skills, which are formed as a result of training, to which a person is subjected during his or her life. The version of Anna Matczak's Social Competence Questionnaire is used to diagnose the effectiveness of functioning in certain situations requiring social interaction. Social competences are understood as acquired skills of coping with social contacts. They condition the effectiveness of functioning in real situations and are formed as a result of training, which is given to a person during his or her life. The version of the questionnaire used contains three scales: (1) Scale I - refers to competences determining the effectiveness of functioning in close social contacts, contains 15 items (maximum score: 60 ); (2) ES scale - refers to competences determining effectiveness in social exposure situations, comprising 18 items (maximum score: (72); (3) Scale A - assesses the competences determining effectiveness in situations requiring assertiveness, consisting of 17 items (maximum score: 68 ). The results of the study may be presented in the form of three partial results, depending on the respective scales, and a general indicator, indicating the overall level of social competence (combined result representing the sum of points for all responses related to social activities (maximum result): 240).

The reliability of the KKS was assessed on the basis of internal consistency, determined both for individual factor scales and for the whole questionnaire. Cronbach's reliability coefficients obtained vary between 0.77 and 0.94 . The relevance of the KKS is good and has been tested by two methods: by checking the factorial accuracy of the tool and by examining its theoretical relevance. The factorial accuracy of the KKS was examined with the use factorial analysis using the main component method, taking into account all 90 items and Varimax rotation analysis to 60 items concerning social competences [15].

\section{Own questionnaire}

The questionnaire contained open questions concerning subjective sources of satisfaction in working for the LOT Passenger Service Department. 


\section{RESULTS}

The analyses were performed using the IBM SPSS Statistics 21 statistical programme. The result distributions of the tested variables verified with the $d$ Kolmogorov-Smirnov test in the sample $(\mathrm{N}=61)$ are characterized by normal distribution.

\section{Differences in the scope of individual social competences of people with different coping styles of stress}

In order to answer the question about differences in social competences caused by extreme results on the continuum of stress management styles, a t-Student test was used. Thus, in the case of a task-oriented approach to dealing with stress, two groups of people with SSZ scores above and below the 63.28 average were distinguished. The first group included persons with SSZ scores in the range 64-77 $(n=26)$ and the second group included persons with results in the range 33-63 $(n=35)$. These results are presented in Table 1.

Tab. 1. The significance of differences in the level of individual social competences among people with low or high intensity of task coping styles of stress.

\begin{tabular}{cccccc}
\hline \multicolumn{6}{c}{$\begin{array}{c}\text { GROUPING VARIABLE: } \\
\text { high vs. low intensity of task coping styles of stress } \\
\text { mean SSZ }=63.28\end{array}$} \\
\cline { 2 - 6 } & $\begin{array}{c}\text { Mean for the } \\
\text { low task coping } \\
\text { styles of stress } \\
(\mathrm{N}=26)\end{array}$ & $\begin{array}{c}\text { Mean for the } \\
\text { high task style } \\
(\mathrm{N}=35)\end{array}$ & value & $\mathrm{p}$ & p Levene \\
\hline I & 41.81 & 45.91 & $-2,42^{*}$ & $0,02^{*}$ & $0,73^{*}$ \\
\hline ES & 49.38 & 52.43 & -1.19 & 0.24 & 0.48 \\
\hline A & 47.42 & 47.91 & -0.22 & 0.83 & 0.93 \\
\hline Wt & 170.46 & 176.97 & -0.96 & 0.34 & 0.45 \\
\hline * significance level $<0,05$ & & & &
\end{tabular}

The results presented in Table 1 show that only the difference in competences determining effectiveness in close social contacts is statistically significant $(t=(-2.42: p<0.05)$. Based on the obtained data, it can be concluded that people whose task coping styles of stress is chosen more often are characterized by higher levels of social competence, which is expressed only in close contacts with other people.

A similar procedure was applied in the case of extreme groups on a SSE scale continuum around an average of 37.36. A group of people with a poorly intensified emotional style of coping with stress in the range of $15-37$ points $(n=29)$ and a group of people who achieved results in the range of 38-61 $(n=32)$ in the SEZ were distinguished. These results are presented in Table 2.
Tab. 2. The significance of differences in the scope of individual social competences in people with a low or high intensity of emotional coping styles of stress.

\begin{tabular}{cccccc}
\hline \multicolumn{6}{c}{ GROUPING VARIABLE: } \\
high vs. low intensity of emotional coping styles of stress \\
mean SSE = 37.36
\end{tabular}

As can be seen from Table 2, people qualified to the group that more often chose an emotional style of coping with stress achieved statistically lower scores in terms of social competences (t-Student 2.89) manifested by a low level of assertiveness.

The next step is to ask about the individual differences between extreme groups on a continuum of the evasive style of coping with stress in the range of the Search for Social Contacts subscale (PKT). This average in the analysed group was 16.57 people. The group of people with a poorly outlined tendency to react by searching for contacts with other people included people, who scored 6-17 points $(n=36)$, while the second group, characterized by a higher tendency to escape from stress into interpersonal relationships included persons in the range from 18 to 24 points $(n=25)$. The obtained results have been presented in Table 3.

Tab. 3. The significance of differences in the scope of individual social competences among people with low or high intensity of social contacts search as a form of evasive coping styles of stress.

\begin{tabular}{cccccc}
\hline \multicolumn{6}{c}{ GROUPING VARIABLE: } \\
high vs. low tendency to seek social contacts as a way of avoiding \\
coping styles of stress \\
mean PKT = 16.57
\end{tabular}

* significance level <0,05

The results obtained suggest that responding to stress by avoiding confrontation with the problem and escaping into interpersonal relationships 
is an excellent training of social skills. The difference in social competences between those who experience such training systematically and those who are not willing to do so is very clearly visible in Table 3 above. As many as three differences are statistically significant: in terms of social competences (I), social expression (ES) and combined result (Wł).

\section{Social competence and satisfaction with LOT Airlines passengers' service}

An additional source of data was the subjective evaluation of satisfaction of the surveyed persons from ground passenger service of the LOT Airlines, based on surveys concerning positive aspects of work in this department. The results obtained are presented in Table 4.

Tab. 4. Ranking of sources of satisfaction with working in the LOT Passenger Service Department $(\mathrm{N}=61)$.

\begin{tabular}{|c|c|c|c|}
\hline & Sources of job satisfaction & $\begin{array}{l}\text { num- } \\
\text { ber of } \\
\text { people }\end{array}$ & $\begin{array}{l}\% \text { of the } \\
\text { surveyed }\end{array}$ \\
\hline 1. & $\begin{array}{l}\text { Contact with people (teamwork, passenger } \\
\text { relations, customer relations) }\end{array}$ & 35 & 39 \\
\hline 2. & $\begin{array}{l}\text { Customer, passenger and co-worker } \\
\text { satisfaction }\end{array}$ & 16 & 18 \\
\hline 3. & Helping passengers, co-workers & 14 & 16 \\
\hline 4. & $\begin{array}{l}\text { Periodical employee evaluation, visible } \\
\text { work effects }\end{array}$ & 11 & 13 \\
\hline 5. & Solving conflicts & 9 & 10 \\
\hline 6. & $\begin{array}{l}\text { Work environment, organization climate } \\
\text { (atmosphere) }\end{array}$ & 8 & 10 \\
\hline 7. & Diversity of duties, work dynamism & 8 & 10 \\
\hline 8. & Making unassisted decisions & 6 & 6 \\
\hline 9. & Possibility of development, self-fulfilment & 5 & 5 \\
\hline 10. & Managing people & 4 & 5 \\
\hline 11. & Organizing work, possibility of planning & 4 & 5 \\
\hline 12. & Prestige (of the place, uniform) & 4 & 5 \\
\hline 13. & Privileges (possibility of travel) & 4 & 5 \\
\hline 14. & Using foreign languages & 3 & 3 \\
\hline 15. & Operations & 3 & 3 \\
\hline 16. & Earnings & 3 & 3 \\
\hline 17. & Possibility of sharing knowledge & 3 & 3 \\
\hline 18. & Shift nature of work & 2 & 2 \\
\hline
\end{tabular}

As can be seen from Table 4, contact with people is the main source of professional satisfaction indicated by the respondents (39\%). Another factor influencing professional satisfaction in terms of frequency ( $18 \%$ of respondents) is the satisfaction of other people, both clients and co-workers, as well as the possibility of providing assistance to others $(16 \%)$. The least frequently mentioned elements determining the satisfaction with work were: shift nature of work, the possibility to influ- ence the opinion on the company and the possibility of correcting mistakes made by others.

\section{DISCUSSION}

The aim of this paper was to determine the relationship between the level of individual social competences and the coping styles of stress, treated in the subject literature as a relatively constant personality trait [3].

On the basis of the conducted research, significant differences were found in the scope of individual social competences of people who prefer different coping styles of stress. For example, people whose task coping styles of stress is more often chosen are characterized by a higher level of social competence, expressed only in close contacts with other people, but this does not apply to assertive behaviours. This is also confirmed by the survey results presented in Table 4, which shows that contact with people is the main source of professional satisfaction indicated by the respondents (39\%). The results in this scope are not fully consistent with earlier studies by other authors [16,18] and theoretical assumptions [12]. In line with the current organisational culture in the workplace, passenger handling staff should be highly assertive. It is also consistent with the assumption of social competence theory that they are taught under the influence of social training $[1,24]$. However, this requires further research on groups of comparative occupations related to and unrelated to the work of customer service, especially as according to the concept of social competences by A. Matczak [15] and social communication by Roloff, M. E., Miller, G. R. [17] only real situations allow us to acquire skills and effectiveness in interpersonal relationships. Interesting are the data indicating that people who more often chose an emotional coping styles of stress achieved statistically lower results in terms of social competences (t-Student 2,89) manifesting in a low level of assertiveness, which is in line with the literature on the subject, that emotions, mainly of anxiety nature, are among others the cause of avoiding social confrontation [3,9]. This is also confirmed by the results presented in Table 2, which indicate differences between the respondents, who are susceptible to training increasing social competences and those who use avoidable strategies of coping with stress, manifested in the search for social contacts but with low expression and low assertiveness level, as pointed out by M. Argyle [1], discussing psychological obstacles in training social skills. 


\section{CONCLUSIONS}

Based on a detailed analysis of the results obtained in the presented research, certain regularities can be observed, from which the following conclusions can be drawn:

1. The results of the research indicate significant differences in the scope of individual social competences among people who prefer different coping styles of stress.

2. Persons with a task-based coping styles of stress had a higher level of social competence.
3. People who show a higher intensity of emotional focused style have been found to be less effective in social performance in the field of assertiveness.

4. People who avoid being confronted with stress, especially in search of social contacts, experience intensive social training and are thus characterised by a higher level of social competences.

\section{AUTHORS' DECLARATION:}

Study Design: Katarzyna Makuch, Jan F. Terelak; Data Collection: Katarzyna Makuch; Statistical Analysis: Katarzyna Makuch, Jan F. Terelak; Manuscript Preparation: Jan F. Terelak; Funds Collection: Katarzyna Makuch, Jan F. Terelak. The Authors declare that there is no conflict of interest.

\section{REFERENCES}

1. Argyle M. Nowe ustalenia w treningu umiejętności społecznych. W: Domachowski, M. Argyle (red.), Reguły życia społecznego. Oksfordzka psychologia społeczna. (s. 197-207). Warszawa: PWN; 1994.

2. Argyle M. Psychologia stosunków międzyludzkich. Warszawa: PWN; 1999.

3. Burleson R.A. Social orientations. W: Croskey, J.C., Daly, J.A. (red.) Personality and interpersonal communication. London: Sage Publication; 1987.

4. Endler N, Parker J. Coping Inventory for Stressful Situations (CISS): Manual. Toronto, Multi-Health Systems, Inc.; 1990.

5. Endler N, Parker J. Assessment of multidimensional coping: Task, emotion and avoidance strategies. Psychological Assessment 1994; 6(1):50-60.

6. Folkman S. Revised coping theory and process of bereavement. In: M.S. Stroebe at al. eds. Handbook of bereavement: Consequences, coping, and care. Washington, DC: American Psychological Association Press; 2001; 563-84.

7. Heszen - Niedojek, I. , (1997). Styl radzenia sobie ze stresem. Fakty i kontrowersje. Czasopismo Psychologiczne; 1997; 3(10): 7-22.

8. Heszen I. Psychologia stresu. Korzystne i niekorzystne skutki stresu życiowego. Warszawa: Wydawnictwo Naukowe PWN; 2013.

9. Jakubowska U., (1996). Wokół pojęcia “kompetencja społeczna” - ujęcie komunikacyjne. Przegląd Psychologiczny 39, 3/4, 29-40.

10. Lazarus RS. Coping theory and research: past, present and future. Psychosomatic Medicine 1993; 55(3): 234-247.

11. Lazarus RS, Folkman S. Stress, appraisal and coping. New York: Springer Publishing Co; 1984.

12. Matczak A. Kwestionariusz Kompetencji społecznych. Studia z Psychologii; 1997; 8: 9-36.

13. Matczak A. Różne oblicza inteligencji: funkcjonowanie intelektu a osobowość. Studia Psychologica, 2001; 2: $157-174$.

14. Matczak A. Temperament a kompetencje społeczne. W: W. Ciarkowska, A. Matczak (red.), Psychologia różnic indywidualnych: Wybrane badania inspirowane Regulacyjną Teorią Temperamentu Profesora Jana Strelaua (s. 53-69); Warszawa: Uniwersytet Warszawski, Interdyscyplinarne Centrum Genetyki Zachowania; 2001.

15. Matczak A. Kwestionariusz Kompetencji Społecznych. Podręcznik. Warszawa: Pracownia Testów Psychologicznych PTP; 2001.

16. Miller SM. (1992). Monitoring and blunting in the face of the threat: Impli cations for adaptation and health. [in:] L. Montand, S.H.Filipp, M.J. Lerner (red.), Life crises and experiences of loss in adulthood; Hillsdale: Lawrence Erlbaum Assoc.; 1992. 
17. Rollof ME., Miller GR (red.). Interpersonal proces: New direction in communication research. London: Sage Publications; 1987.

18. Spitzberg RH., Cupach W.R. Handbook of interpersonal competence research. New York: Springer - Verlag Inc.; 1989.

19. Sternberg, RJ. (1990). Metaphors of mind: Conceptions of the nature of intelligence. Cambridge: University Press.

20. Strelau J, Jaworowska A, Wrześniewski K, Szczepaniak P. Kwestionariusz Radzenia sobie w sytuacjach stresowych. CISS. Podręcznik, Warszawa, Pracownia Testów Psychologicznych PTP; 2005.

21. Terelak JF. Studia z psychologii stresu. Warszawa: Wydawnictwo ATK; 1997.

22. Terelak JF. Stres życia: Perspektywa psychologiczna. Warszawa: Wydawnictwo Naukowe UKSW; 2017.

23. Thorndike EL. The measurement of intelligence. New York: Teachers College; 1927.

24. Weinstein E.A. The development of interpersonal competence: Handbook of socialization theory and research. Chicago: Rond Mc Nelly; 1969.

25. Wrześniewski K. Style radzenia sobie ze stresem: Problemy pomiaru. (w): Heszen-Niejodek I., Ratajczak Z. (red.). Człowiek w sytuacji stresu. Problemy teoretyczne i metodologiczne. Katowice: Wydawnictwo Uniwersytetu Śląskiego; 2000: 44-63.

\section{ACKNOWLEDGEMENTS}

The views, opinions, and findings contained in this article are our own and should not be construed as an official Polish Air Force position, policy, or decision, unless so designated by other official documentation.

Cite this article as: Terelak JF, Makuch K. Coping Styles Of Stress And The Level Of Social Competence Of The Staff Members Involved In The Handling Of Passengers On Lot Polish Airlines' Flights. Pol J Aviat Med Bioeng Psychol 2016; 22(4): 5-12. DOI: 10.13174/ pjambp.23.02.2018.01 